\title{
Facultative methanotrophs are abundant at terrestrial natural gas seeps
}

\author{
Muhammad Farhan UI Haque ${ }^{1}$, Andrew T. Crombie ${ }^{2}$, Scott A. Ensminger ${ }^{3}$, Calin Baciu ${ }^{4}$ and J. Colin Murrell ${ }^{1^{*}}$
}

\begin{abstract}
Background: Natural gas contains methane and the gaseous alkanes ethane, propane and butane, which collectively influence atmospheric chemistry and cause global warming. Methane-oxidising bacteria, methanotrophs, are crucial in mitigating emissions of methane as they oxidise most of the methane produced in soils and the subsurface before it reaches the atmosphere. Methanotrophs are usually obligate, i.e. grow only on methane and not on longer chain alkanes. Bacteria that grow on the other gaseous alkanes in natural gas such as propane have also been characterised, but they do not grow on methane. Recently, it was shown that the facultative methanotroph Methylocella silvestris grew on ethane and propane, other components of natural gas, in addition to methane. Therefore, we hypothesised that Methylocella may be prevalent at natural gas seeps and might play a major role in consuming all components of this potent greenhouse gas mixture before it is released to the atmosphere.
\end{abstract}

Results: Environments known to be exposed to biogenic methane emissions or thermogenic natural gas seeps were surveyed for methanotrophs. 16S rRNA gene amplicon sequencing revealed that Methylocella were the most abundant methanotrophs in natural gas seep environments. New Methylocella-specific molecular tools targeting mmoX (encoding the soluble methane monooxygenase) by PCR and Illumina amplicon sequencing were designed and used to investigate various sites. Functional gene-based assays confirmed that Methylocella were present in all of the natural gas seep sites tested here. This might be due to its ability to use methane and other short chain alkane components of natural gas. We also observed the abundance of Methylocella in other environments exposed to biogenic methane, suggesting that Methylocella has been overlooked in the past as previous ecological studies of methanotrophs often used pmoA (encoding the alpha subunit of particulate methane monooxygenase) as a marker gene.

Conclusion: New biomolecular tools designed in this study have expanded our ability to detect, and our knowledge of the environmental distribution of Methylocella, a unique facultative methanotroph. This study has revealed that Methylocella are particularly abundant at natural gas seeps and may play a significant role in biogeochemical cycling of gaseous hydrocarbons.

Keywords: Methylocella, Facultative methanotrophs, Natural gas, Geological methane, Biological methane, Methane monooxygenase, mmoX

\section{Background}

Methane is an integral component of the global carbon (C) cycle and one of the most significant contributors to climate change since it has a global warming potential approximately 34 times greater than carbon dioxide [1]. Atmospheric concentrations of methane have been steadily rising since the Industrial Revolution, currently around $1.8 \mathrm{ppm}$ by volume [2]. Approximately $70 \%$ of the total

\footnotetext{
* Correspondence: j.c.murrell@uea.ac.uk

${ }^{1}$ School of Environmental Sciences, University of East Anglia, Norwich

Research Park, Norwich NR4 7TJ, UK

Full list of author information is available at the end of the article
}

500 to 600 million tonnes methane emitted [2] is new methane, i.e. produced by methanogens during microbial degradation of organic matter, largely under anaerobic conditions. This biological process is particularly prevalent in wetlands, landfills, rice paddies, the rumen of cattle and the hindgut of termites. The remaining $30 \%$ of the methane released into the atmosphere arises from the thermogenic decomposition of fossil organic material to geological methane and other gases collectively known as natural gas [2]. Natural gas consists usually of geological methane and substantial amounts of the short chain alkanes ethane, propane and butane [3], and from 
subsurface reservoirs it reaches the surface of the Earth through natural seepage or mining and extraction activities.

Globally, geological methane from natural gas seeps is the second largest natural source, after wetlands, and apart from methane, it also contributes up to 3-6 million tonnes of climate-active ethane and propane per year [4]. Seepage of natural gas occurs in a wide range of environments, e.g. hydrocarbon-prone sedimentary basins, both as visible features including dry gas seeps and mud volcanoes, or in the marine realm as hydrothermal vents or shallow marine methane seeps, but also as invisible microseepage [3, 5-8]. Volcanic and geothermal systems, hot and cold springs or alkaline soda lakes, may also release non-negligible amounts of methane [9-11]. Spectacular releases of natural gas are observed at the Eternal Flame Falls in Chestnut Ridge Park, New York, where seep gas contains methane plus $35 \%$ ethane and propane [12]. Gas releases caused by human activity range from incidents such as the Deepwater Horizon disaster of 2010 (where 170,000 tonnes of natural gas escaped to the marine environment) to operational releases including leaking gas pipelines and coal mining activities [13]. Unintentional releases of natural gas are widespread and likely to increase, especially with the exploitation of unconventional resources including shale gas extraction, with associated concerns of environmental pollution and climate change [14-17].

Although a vast amount of methane escapes to the atmosphere, much more would escape if it were not for the activity of microbes that consume methane. Over half of the methane produced by methanogens in wetlands has been reported to be consumed by aerobic methanotrophs [18-20]. These methane-oxidising bacteria are a remarkable group of microbes that use methane as their sole source of carbon and energy. Aerobic methanotrophs are mainly Gram-negative bacteria of the classes Alphaproteobacteria and Gammaproteobacteria. They are usually obligate methanotrophs, unable to grow on other alkanes and multi-carbon compounds, except for only a few strains, which can grow on acetate and ethanol [21, 22]. During the metabolism of methane by aerobic bacteria, the first step is the oxidation of methane to methanol, which is catalysed by one of two enzymes: a membrane-bound, copper-containing particulate methane monooxygenase (pMMO) or a diiron centre containing soluble methane monooxygenase (sMMO) [23-26]. Both conventional enrichment experiments and cultivation-independent studies indicate that obligate methanotrophs are widespread in the environment, especially in areas rich in methane [27-30].

Specialised microbes growing on other gaseous alkanes such as ethane or propane (propanotrophs) have also been characterised, including metabolically versatile Actinobacteria (Rhodococcus and Mycobacterium) [31-33],
Gammaproteobacteria (Psuedomonas) [34] or Betaproteobacteria (Thauera) [35, 36] that grow on many multi-carbon compounds. Most propanotrophs contain a propane monooxygenase enzyme (PrMO) with similarities to sMMO but do not grow on methane [37, 38]. An exciting development in the study of biological methane oxidation was the isolation of facultative methanotrophic strains of the genus Methylocella from acidic peat, tundra and forest soils [39-41]. These unusual methanotrophs grow on methane as well as some multi-carbon compounds including acetate, pyruvate, succinate and gluconate [42, 43]. Methylocella belong to alphaproteobacterial family Beijerinckiaceae containing generalist organotrophs (e.g. Beijerinckia indica), facultative methanotrophs (e.g. Methylocella silvestris) and obligate methanotrophs (e.g. Methylocapsa acidiphilia) [44]. Examination of the Methylocella silvestris BL2 genome revealed that unlike most methanotrophs, Methylocella did not contain genes for pMMO but oxidised methane using the sMMO enzyme only [45]. Surprisingly, genes encoding a PrMO were also identified in the Methylocella silvestris BL2 genome. Crombie and Murrell [46] reported for the first time that Methylocella silvestris BL2 derives growth benefits from oxidising methane and propane simultaneously using two distinct enzymes, sMMO and PrMO. This discovery overturned the dogma that degradation of methane and other alkane components of natural gas requires different groups of microbes.

The unique metabolic capabilities of Methylocella have profound implications for the biological consumption of natural gas in the environment. Methylocella, being able to use most components of natural gas for growth, may have a competitive edge over less versatile obligate methanotrophs and propanotrophs in environments rich in natural gas. As little is known about the distribution of Methylocella in the environment, the purposes of this study were to improve molecular methods for detection of Methylocella in environmental samples and to test the hypothesis that Methylocella-like facultative methanotrophs are prevalent in thermogenic, natural gas seep environments.

\section{Results and discussion}

Methanotrophs present at biogenic methane and natural gas seep environments

Since Methylocella species are the only methanotrophs known to use methane and the other components of natural gas such as ethane and propane simultaneously [46], we hypothesised that Methylocella may be abundant in environments exposed to thermogenic natural gas seeps. For centuries, natural gas seeps have been reported in New York state, part of the Appalachian Basin in the USA [47-49], exemplified by towns such as 
Gasport (Niagara County), named in 1826. Many of these seeps emit natural gas, which can be ignited (Additional file 1: Figure S1). The best-known example of such seep sites is the "Eternal Flame" in Chestnut Ridge National Park [12]. We explored many such documented and undocumented thermogenic gas seeps in this region for sample collection and found that methane and also considerable amounts of ethane and propane were present in gas collected directly from the seep sites (Additional file 1: Table S1).

Libraries of $16 \mathrm{~S}$ rRNA genes were generated from DNA extracted from samples from diverse environments known to be exposed to biogenic methane or thermogenic natural gas seeps (Fig. 1). Illumina Mi-Seq yielded 617,613 good quality sequence reads in total from 15 samples, averaging 41,178 sequences per sample (Additional file 2: Table S2). Sequence analysis showed that out of 20 phyla at an abundance of higher than 1\% in one or more of the samples, Proteobacteria (alpha, beta and gamma), Actinobacteria, Acidobacteria, Bacteroidetes, Chloroflexi, Firmicutes, Planctomycetes and Verrucomicrobia contributed substantially to the bacterial communities (Fig. 1). Dominant families included Acidobacteriaceae (Moor House Nature Reserve), Comamonadaceae (Ellicott Creek and Eternal Flame Falls), Flavobacteriaceae (Ellicott Creek and Eternal Flame Falls, Eighteen Mile Creek and Gasport), Hyphomicrobiaceae (Lakenheath Fen Nature Reserve), Porphyromonadaceae (Ellicott Creek, Pipe Creek), Mycobacteraceae (Andreiasu Everlasting Fire), Verrucomicrobiaceae (Pipe Creek, Gasport), Campylobacteraceae (Movile Cave mat) and Beijerinckiaceae (Pipe Creek). When analysed at the genus level, 16S rRNA gene sequences were resolved into 1062 operational taxonomic units (OTUs), of which 129 OTUs were found at an abundance of higher than $1 \%$ in at least one sample (Additional file 2: Table S2).

Detailed analysis of $16 \mathrm{~S}$ rRNA gene amplicons revealed that of the methanotrophs, the genera Methylobacter, Methylocella, Methylococcus, Methylocystis, Methylosinus and possibly Verrucomicrobia dominated all samples (Fig. 2). Methanotrophs accounted for 0.62$17.90 \%$ of the total bacterial population present in all 15 environmental samples (Fig. 2). Methylocystis, Methylosinus, Methylocella and Verrucomicrobia dominated in samples from sites of biogenic methane emissions (Lakenheath Fen Nature Reserve and Moor House Nature Reserve) (Fig. 2). Methylococcus, Verrucomicrobia and Methylocella were abundant in Andreiasu Everlasting Fire (Fig. 2), a Romanian mud volcano site reported to have largely thermogenic natural gas emissions $[5,6]$ but with the potential of biogenic methane emissions as revealed by the presence of methanogenic archaea in nearby mud volcanoes [50]. Methylocystis, Methylobacter and Methylocella were the dominant methanotrophs in microbial mat samples from Movile Cave, a very unusual, dark chemoautotrophic habitat also known to contain methane from both biogenic and thermogenic activities [51-53]. Like other environmental samples tested in this study, Verrucomicrobia were also found in Movile Cave samples, but we are not certain if the Verrucomicrobia detected by $16 \mathrm{~S}$ rRNA in these environmental samples were methanotrophic or non-methano trophic. Many other methanotrophic genera such as $\mathrm{Clo-}$ nothrix, Methylohalobius, Methylomagnum, Methylomarinovum, Methyloparacoccus, Methyloprofundus, Methylosarcina and Methyloterricola were not found in any of the tested samples. Interestingly, the facultative methanotroph, Methylocella, was the most abundant methanotroph in samples from natural gas seep environments (with the exception of Gasport samples) and accounted for $25-64 \%$ of total methanotrophs in samples from thermogenic natural gas seeps of Ellicott Creek, Pipe Creek, Eternal Flame Falls and Eighteen Mile Creek (Fig. 2). Methylocella appeared to be the indicator methanotrophic genus in most natural gas seep sites (Additional file 1: Figure S2). Methylocella abundance and the proportion of ethane and propane showed a positive correlation (Spearman's rank correlation coefficient $=0.80, P$ value $=0.03$ ). Metabolic versatility and the capability of utilising ethane and propane along with methane may confer an advantage over obligate methanotrophs, allowing Methylocella to colonise environments exposed to propane and ethane as well as methane. Methylocella silvestris BL2 exhibits higher growth rates and carbon conversion rates when grown under a mixture of propane and methane as compared to growth on either of these gases alone [46]. The presence of ethane and propane alongside methane at certain sites (Additional file 1: Table S1) and the abundance of Methylocella in those environments tested here supports our hypothesis that Methylocella may have a competitive advantage over obligate methanotrophs in natural gas seep sites.

\section{Distribution and abundance of Methylocella in different environments}

Since 16S rRNA gene taxonomy might not distinguish between methanotrophic and non-methanotrophic members of the Beijerinckiaceae family (Additional file 1: Table S3) [44], we developed a Methylocella-specific PCR assay targeting $m m o X$ (encoding the sMMO active site subunit) to study the distribution of Methylocella at various sites. The use of probes targeting a bacterial functional gene rather than the 16S rRNA gene enables a much more sensitive evaluation of microbial diversity in complex environments as it limits the investigation to the functional group being studied [54]. PCR conditions for Methylocella-specific $m m o X$ were optimised and validated with DNA from pure cultures of known 


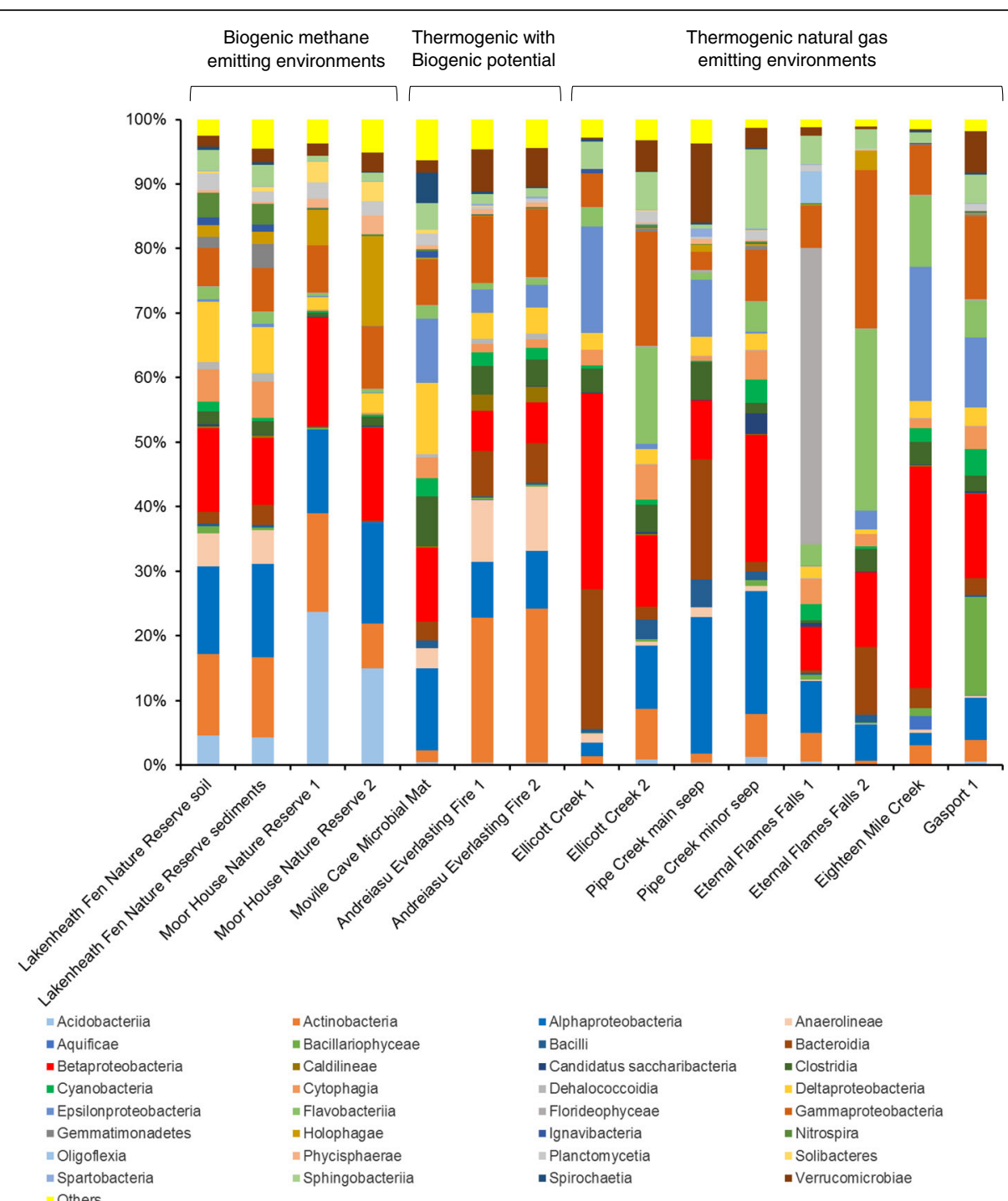

Fig. 1 Relative abundance (\%) of dominant bacterial classes in different environments as revealed by 165 rRNA gene sequencing. Amplicon sequencing was performed on DNA samples from environments exposed to biogenic methane and/or natural gas emissions

methanotrophs (Additional file 1: Figure S3); including a newly isolated strain Methylocella silvestris TVC [55]. DNA extracted from various environmental samples was PCR-screened for Methylocella-specific mmoX genes (Table 1). Of the 31 samples originating from diverse locations where there are biogenic methane and/or thermogenic natural gas emissions, Methylocella-specific $m m o X$ gene PCR products were detected in 25 samples (Table 1), from both types of environments, i.e. biogenic methane emitting and/or thermogenic natural gas emitting. Methylocella-specific mmoX was detected in samples from biogenic methane-emitting environments with slightly acidic to moderately acidic $\mathrm{pH}$ (e.g. Lakenheath Fen Nature Reserve and Moor House Nature Reserve) and was detected in all the samples from natural gas-emitting sites regardless of $\mathrm{pH}$ (Table 1). There are a few environments, e.g. Movile Cave, which have previously been reported to be negative for Methylocella [56], but we now detect Methylocella-specific mmoX from wall scrapings in this environment (Table 1), in agreement with a recent metagenomics study [57]. This suggests that our newly designed PCR assay for mmoX showed better sensitivity and specificity for Methylocella as compared to the previously reported assay [56]. Another PCR assay to detect $m m o X$ of Methylocella was described earlier, but the authors were unable to show any Methylocella-specific mmoX amplified from environmental samples [58]. Specificities of the new primers and an optimised protocol to detect Methylocella-specific $m m o X$ genes in DNA from environmental samples reported here were verified by constructing $m m o X$-amplicon clone libraries and Illumina amplicon sequencing. 


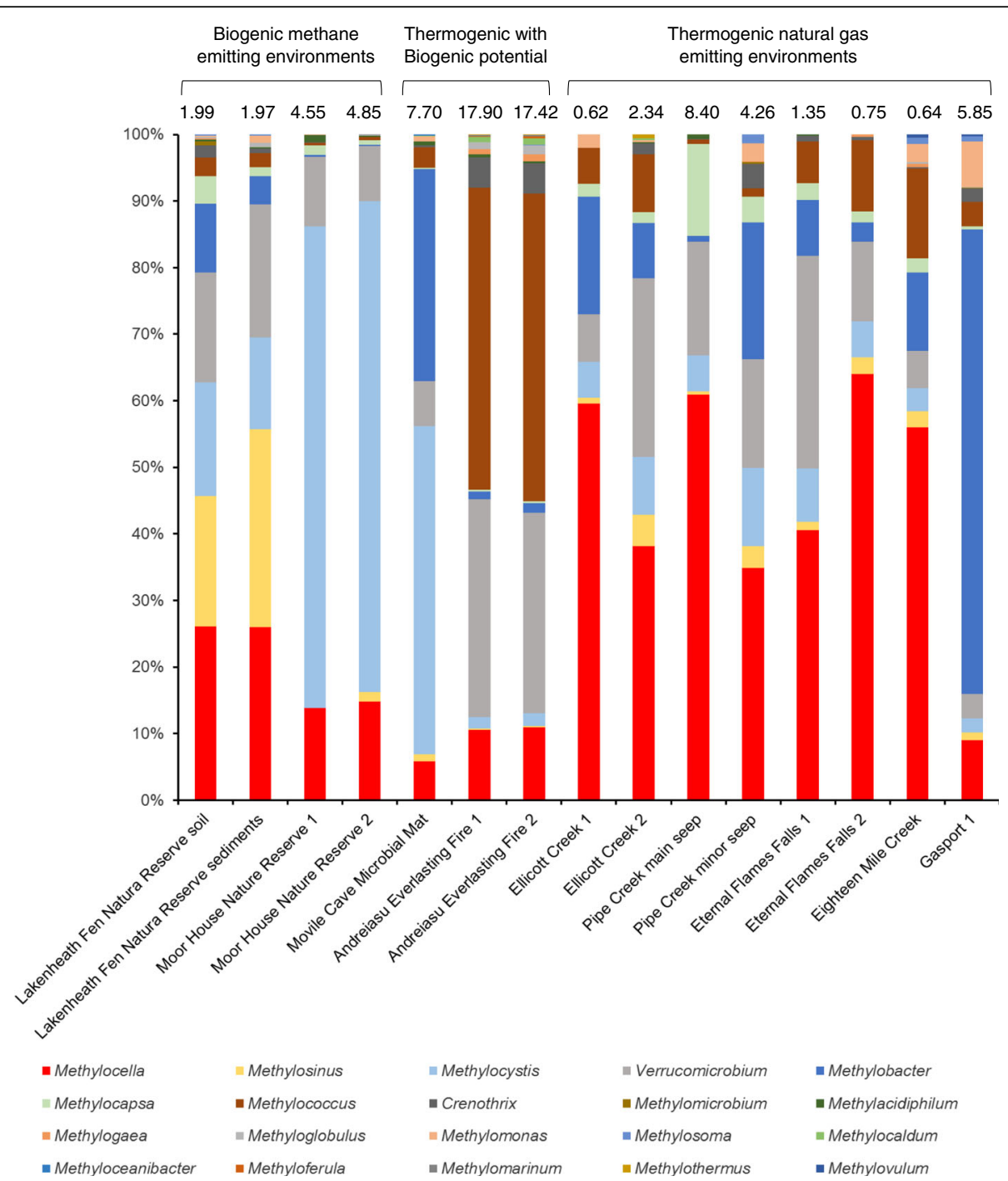

Fig. 2 Relative abundance (\%) of methanotrophic bacteria in environmental samples as revealed by 165 rRNA gene sequencing. Amplicon sequencing was performed on DNA samples from environments exposed to biogenic methane and/or natural gas emissions. The proportion (\%) of the combined methanotrophic population in each environment is shown above each bar, based on the abundance of 16S rRNA gene sequences of known methanotrophs (data filtered from Additional file 2: Table S2)

Previously, only a few cultivation-dependent studies [39-41, 59-61] and cultivation-independent studies (for example [56, 62-67]) have detected Methylocella in a relatively small number of environments. Methylocella had been reported in many studies to be abundant in acidic soils [68], and the known Methylocella species had been isolated only from acidic soil environments including peat bogs, forest and tundra soils [39-41]. Their abundance in acidic environments may be due to the ability of Methylocella to use readily available acetate [42], a major intermediate of carbon turnover in these soils [42, 69]. Rahman et al. [56] reported for the first time that Methylocella are not limited to acidic environments as they detected Methylocella-specific mmoX in the alkaline environments of Lonar Lake ( $\mathrm{pH} 10)$. Here, we also confirmed that the distribution of Methylocella is not limited to acidic environments as mmoX of Methylocella was detected in all environmental samples from thermogenic natural gas-emitting sites of acidic and basic $\mathrm{pH}$ (Table 1), possibly because of the metabolic flexibility and ability of Methylocella to utilise methane and propane in the environments where these gases co-occur. Our results show that Methylocella thrive best in environments with thermogenic natural gas emissions under various $\mathrm{pH}$ conditions (Table 1, Fig. 2).

Our results show that Methylocella not only dominated natural gas seep sites but they are also abundant in other environments (Fig. 2) confirming previous observations [56] that Methylocella-like facultative methanotrophs are widespread and abundant. Frequently, 
Table 1 Detection of Methylocella using a functional gene-based PCR assay

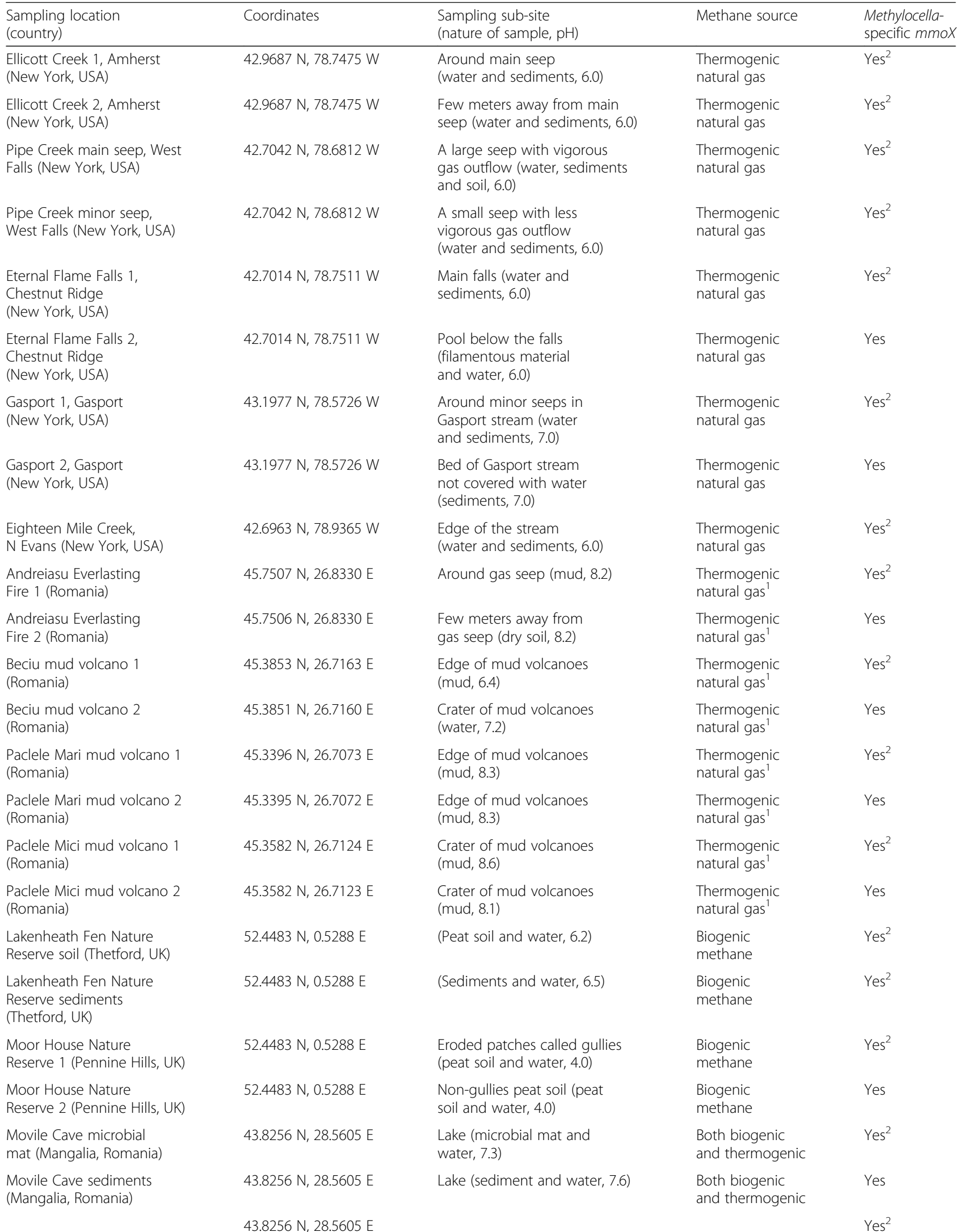


Table 1 Detection of Methylocella using a functional gene-based PCR assay (Continued)

\begin{tabular}{|c|c|c|c|c|}
\hline $\begin{array}{l}\text { Sampling location } \\
\text { (country) }\end{array}$ & Coordinates & $\begin{array}{l}\text { Sampling sub-site } \\
\text { (nature of sample, pH) }\end{array}$ & Methane source & $\begin{array}{l}\text { Methylocella- } \\
\text { specific } m \text { moX }\end{array}$ \\
\hline $\begin{array}{l}\text { Movile Cave scrapings } \\
\text { (Mangalia, Romania) }\end{array}$ & & $\begin{array}{l}\text { Air bell walls (soft solid } \\
\text { material from walls, } 7.3 \text { ) }\end{array}$ & $\begin{array}{l}\text { Both biogenic } \\
\text { and thermogenic }\end{array}$ & \\
\hline $\begin{array}{l}\text { Church Farm soil } 1 \\
\text { (Bawburgh, UK) }\end{array}$ & $52.6167 \mathrm{~N}, 1.1667 \mathrm{E}$ & (Soil, 7.0) & $\begin{array}{l}\text { Biogenic } \\
\text { methane }\end{array}$ & No \\
\hline $\begin{array}{l}\text { Church Farm soil } 2 \\
\text { (Bawburgh, UK) }\end{array}$ & $52.6167 \mathrm{~N}, 1.1667 \mathrm{E}$ & (Soil, 7.0) & $\begin{array}{l}\text { Biogenic } \\
\text { methane }\end{array}$ & No \\
\hline $\begin{array}{l}\text { Strumpshaw landfill } \\
\text { (Norfolk, UK) }\end{array}$ & $52.6027 \mathrm{~N}, 1.4791 \mathrm{E}$ & $\begin{array}{l}\text { Soil biofilter from } \\
\text { a closed landfill } \\
(\text { soil, } 7.0)\end{array}$ & $\begin{array}{l}\text { Biogenic } \\
\text { methane }\end{array}$ & $\mathrm{Yes}^{2}$ \\
\hline $\begin{array}{l}\text { Stiffkey Fen and Salt } \\
\text { Marshes } 1 \text { (Norfolk, UK) }\end{array}$ & $52.9650 \mathrm{~N}, 0.9253 \mathrm{E}$ & (Soil, 7.0) & $\begin{array}{l}\text { Biogenic } \\
\text { methane }\end{array}$ & No \\
\hline $\begin{array}{l}\text { Stiffkey Fen and Salt } \\
\text { Marshes } 2 \text { (Norfolk, UK) }\end{array}$ & $52.9650 \mathrm{~N}, 0.9253 \mathrm{E}$ & (Soil, 7.0) & $\begin{array}{l}\text { Biogenic } \\
\text { methane }\end{array}$ & No \\
\hline $\begin{array}{l}\text { Warham Salt Marsh } \\
\text { (Norfolk, UK) }\end{array}$ & $52.9617 \mathrm{~N}, 0.89667 \mathrm{E}$ & $\begin{array}{l}\text { Sulphur enriched salt } \\
\text { marsh (wet soil, 7.2) }\end{array}$ & $\begin{array}{l}\text { Biogenic } \\
\text { methane }\end{array}$ & No \\
\hline $\begin{array}{l}\text { Warham Salt Marsh } \\
\text { (Norfolk, UK) }\end{array}$ & $52.9617 \mathrm{~N}, 0.89667 \mathrm{E}$ & $\begin{array}{l}\text { Iron-enriched salt marsh } \\
\text { (wet soil, 6.8) }\end{array}$ & $\begin{array}{l}\text { Biogenic } \\
\text { methane }\end{array}$ & No \\
\hline
\end{tabular}

${ }^{1}$ These sites have been reported to have largely thermogenic natural gas emissions $[5,6]$ but with potential for biogenic methane [50]

${ }^{2}$ Methylocella-specific $m m o X$ verified by the construction of clone libraries from PCR products and sequencing of cloned $m m o X$ fragments

molecular ecology studies of methanotrophs have targeted the $p m o A$ gene $[18,27,28]$ encoding a key subunit of pMMO. Methylocella is unusual because it lacks pMMO and instead uses sMMO to oxidise methane [45]. The abundance of Methylocella in the different environments tested in this study reveals that facultative methanotrophs may have been overlooked in many cultivation-independent studies that targeted only pmoA. The use of both $p m o A$ and $m m o X$, as genetic markers for ecological studies, is therefore important to avoid underestimating the diversity and abundance of methanotrophs in the environment. More methanotrophs that only contain sMMO and lack pMMO are being discovered $[70,71]$. Therefore, there is a need to re-examine functional gene primers targeting $m m o X$ to detect all methanotrophs containing only sMMO.

In addition to the $16 \mathrm{~S}$ rRNA amplicon sequencing data, Methylocella abundance was also estimated by a newly developed qPCR assay targeting the Methylocella-specific mmoX. The abundance of Methylocella detected in selected environmental samples varied from $4.59( \pm 0.19) \times 10^{6}$ (Moor House Nature Reserve, UK) to $2.55( \pm 0.06) \times 10^{8}$ cells g $^{-1}$ sample (Pipe Creek main seep, New York, USA) (Fig. 3). The abundance of Methylocella-specific mmoX was an order of magnitude higher in Pipe Creek main seep samples compared to other tested samples (Additional file 1: Figure S4). In contrast, the abundance of $p m o A$-containing methanotrophs in these environmental samples varied from 3.68 $( \pm 0.12) \times 10^{7} \quad$ (Movile Cave Microbial Mat) to 1.61 $( \pm 0.30) \times 10^{8}$ pmoA copies $\mathrm{g}^{-1}$ sample (Lakenheath Fen Nature Reserve) (Fig. 3). Remarkably, in the samples from the Pipe Creek main seep, the Methylocella population alone constituted $5-12 \%$ of the total bacteria or $60-85 \%$ of the total methanotroph population (as estimated by $16 \mathrm{~S}$ rRNA gene amplicon sequencing and Methylocella-specific $m m o X$ qPCR respectively) (Figs. 2 and 3). In comparison to peat soils previously described as favourable habitats for Methylocella [56, 68], the Methylocella population was an order of magnitude higher in the natural gas seep site of Pipe Creek.

\section{Phylogenetic analysis of $m m o X$ from Methylocella}

Sequence analysis of the clone libraries generated from the Methylocella-specific mmoX PCR products obtained with different environmental DNA samples showed that most sequences are similar to known Methylocella-specific $m m o X$ sequences in the NCBI database. These similarities ranged from 80 to $100 \%$ suggesting the possibility of novel diversity in Methylocella-specific $m m o X$ sequences. Detailed analyses of the composition and diversity of Methylocella using Illumina Mi-Seq sequencing of Methylocella-specific mmoX PCR amplicons from environments exposed to thermogenic natural gas seeps and/or biogenic methane emissions were also performed. Methylocella-specific mmoX amplicon sequencing yielded 849,221 quality-filtered sequences in total for 15 samples averaging 56,615 per sample. Following sequence analysis using SwarmV2 [72], 34 OTUs with a relative abundance of higher than $1 \%$ were recovered from all samples (Additional file 3: Table S4). Phylogenetic analysis based on the DNA nucleotide sequences of the library clones and OTUs recovered from amplicon sequencing show that $m m o X$ sequences clustered in several distinct clades (Fig. 4). OTUs 


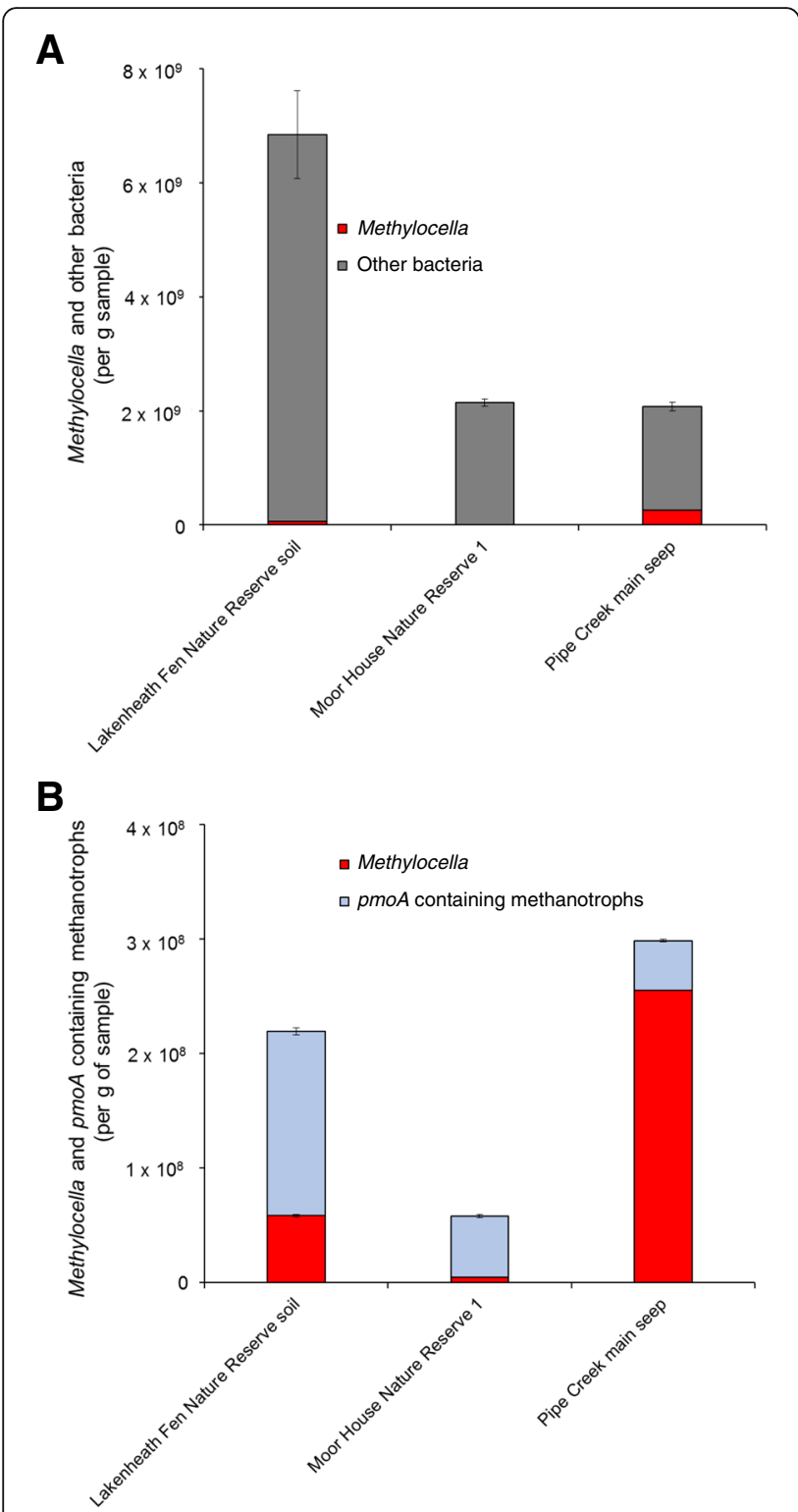

Fig. 3 Abundance of Methylocella in relation to total bacteria (a) and pmoA-containing methanotrophs (b). Bacterial populations were enumerated by qPCR of 165 rRNA (for total bacteria), Methylocellaspecific mmoX (for Methylocella) and pmoA (for pmoA-containing methanotrophs) genes on environmental DNA samples. Methylocella cell numbers equate to Methylocella-specific mmoX gene copies, whereas bacteria and pmoA-containing methanotrophs were assumed to contain two $16 \mathrm{~S}$ rRNA or pmoA gene copies per cell. Bacteria other than Methylocella were enumerated by subtracting Methylocella from total bacterial cell numbers. Error bars represent the propagated errors based on standard deviation of triplicate samples

clustering around Methylocella tundrae T4 and Methylocella silvestris BL2 were abundant in samples from Lakenheath Fen Nature Reserve soil, Pipe Creek, Eternal Flame Falls and Andreiasu Everlasting Fire while those clustering around Methylocella palustris K were abundant in samples from Moor House Nature Reserve samples (Fig. 4,
Additional file 3: Table S4). Interestingly, a few Methylocella-specific mmoX clones and OTUs originating from Lakenheath Fen Nature Reserve, Ellicott Creek and Eighteen Mile Creek did not cluster with other known $m m o X$ sequences (cluster IV and V in Fig. 4). BLAST analyses of the clones (e.g. clone AM1-6 Ellicott Creek 1, AM2-2 Ellicott Creek 2, AM2-3 Ellicott Creek 2) from this cluster further revealed their best hit to the $m m o X$ from Methylocella silvestris BL2 but with only $81 \%$ nucleotide identity, suggesting that these environments harbour novel strains, possibly related to Methylocella. In some environments where Methylocella was not abundant, we also detected some sequences (OTUs 6, 7, 8, 25, 34 and 80) more closely related to $m m o X$ from other methanotrophs. These false positives made up approximately $10 \%$ (less than $5 \%$ in clone libraries) of the total sequences reads (Fig. 4). However, this non-Methylocella mmoX OTU appeared to be a dominant taxon (72\%) based on mmoX amplicon sequencing in Eighteen Mile Creek sample (Fig. 4, Additional file 3: Table S4). Therefore, a clone library or amplicon sequencing analysis should be performed to validate the results of Methylocella-specific mmoX PCR or qPCR. Phylogenetic clustering of the sequences from clone libraries and amplicon sequencing from the same samples was remarkably congruent (Fig. 4, Additional file 3: Table S4). Comparison of the different environments revealed that Pipe Creek natural gas seep was the most diverse in terms of Methylocella-specific mmoX (Additional file 3: Table S4). Although it was not possible to link Methylocella-specific mmoX diversity with either biogenic methane-emitting environments or thermogenic natural gas-emitting environments, this phylogenetic analysis suggests the possibility of novel diversity in Methylocella-specific mmoX sequences and has suggested several target sites for future isolation of new Methylocella strains.

\section{Conclusions}

New biomolecular tools designed in this study have expanded our knowledge of the environmental distribution of the facultative methanotroph Methylocella. Methylocella-like facultative methanotrophs are particularly abundant at natural gas seeps and may therefore play a significant role in biogeochemical cycling of these gaseous alkanes. This study is timely since the release of natural gas into the environment globally will increase considerably with the exploitation of unconventional sources of oil and gas. A detailed mechanistic understanding of how Methylocella-like facultative methanotrophs mitigate these fugitive gases can now be undertaken using the tools and knowledge obtained in this study. In situ estimates of the activity of Methylocella oxidising methane and other alkanes simultaneously at natural gas seeps are now required to 


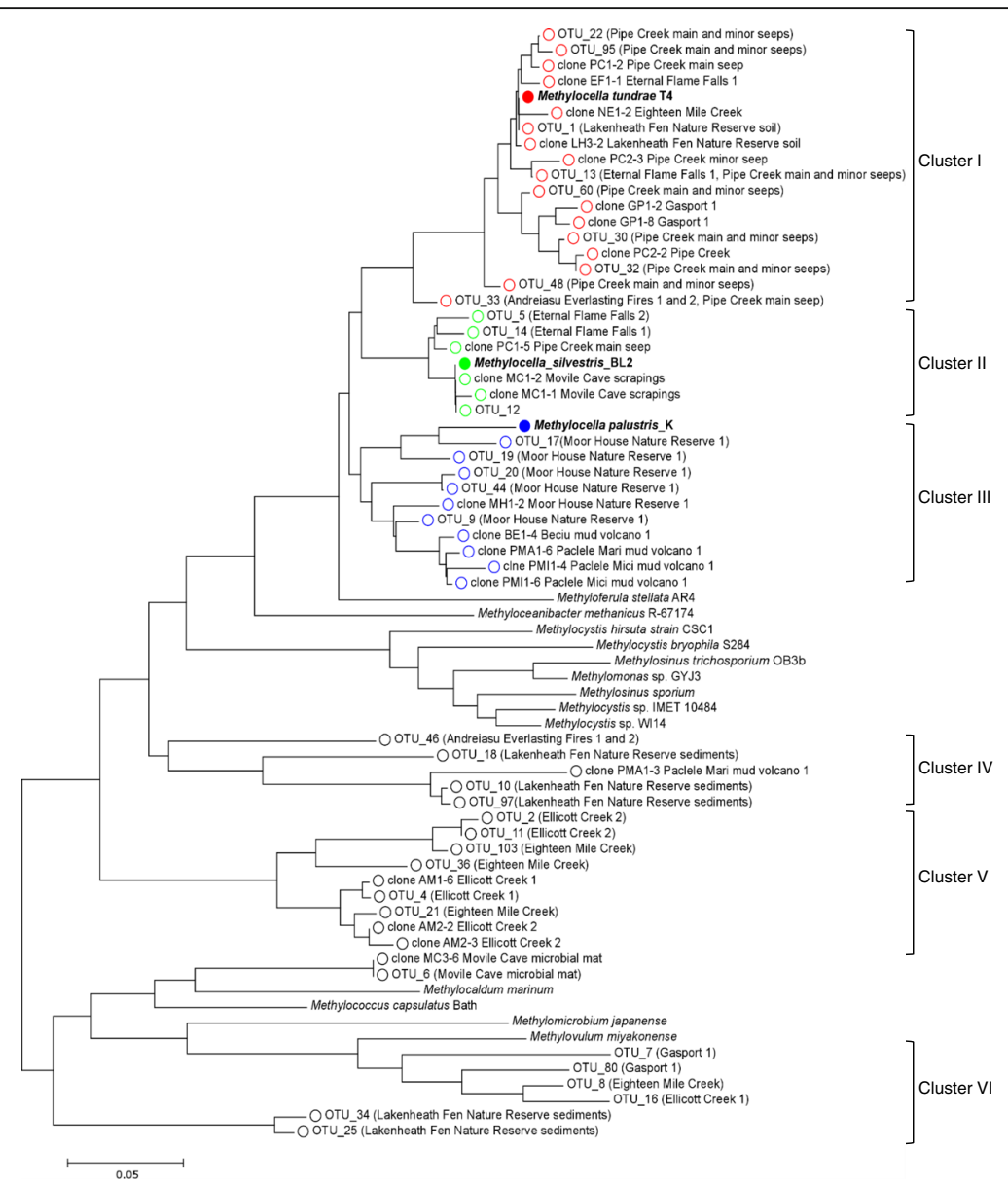

Fig. 4 Phylogenetic tree of Methylocella-specific mmoX clones and operational taxonomical units (OTUs) retrieved by amplicon sequencing from various environmental DNA samples. Methylocella-specific mmoX clones and OTUs are grouped either around Methylocella tundrae T4 (red circles), Methylocella silvestris BL2 (green circles), Methylocella palustris K (blue circles) or distantly (black circles) from any known Methylocella strains (solid symbols). Environments where a particular OTU is abundant are shown in brackets. Partial mmoX sequences of representative clones and OTUs (abundance higher than 1\%) and mmoX sequences from characterised methanotrophic bacterial strains were aligned using Mega 7.0. The optimal tree with the sum of branch length = 2.98 is shown where the evolutionary history was inferred using the neighbour-joining method taking into account a total of 323 nucleotide positions in the final dataset. The percentage (greater than 50\%) of replicate trees in which the associated taxa clustered together in the bootstrap test (1000 replicates) are shown next to the branches. Scale bar represents 0.05 substitutions per site

determine their impact on the cycling of these atmospheric trace gases.

\section{Methods}

\section{Chemicals and reagents}

All chemicals and reagents (purity $>99 \%$ ) were obtained from Sigma-Aldrich unless otherwise stated. Buffers, culture media and solutions were prepared in ultra-pure water, and sterilisation was done by autoclaving $\left(15 \mathrm{~min}, 121^{\circ} \mathrm{C}, 1 \mathrm{bar}\right)$ or by filtration $(0.2 \mu \mathrm{m})$.

\section{Bacterial strains and growth conditions}

Methylocella strains were grown in $20 \mathrm{ml}$ diluted nitrate mineral salt (DNMS) medium, and other methanotrophs were grown using nitrate mineral salt (NMS) medium, in $120 \mathrm{ml}$ serum vials, with methane $(20 \% v / v$ in headspace) as the only source of $\mathrm{C}$ and energy, as described previously $[73,74]$. The growth of liquid cultures was monitored by measuring the optical density at $540 \mathrm{~nm}$.

\section{Sample collection and characterisation}

To study the distribution of Methylocella-like methanotrophs, samples (soil or sediment and water) were taken from diverse environments with known emissions of biogenic methane and/or thermogenic natural gas (see Table 1 and Additional file 1: Table S1 for details). Several natural gas seeps have been reported in New York state, USA [12], and Romania [5, 6]. Five locations in New York state known to emit thermogenic natural gas were sampled in June 2017 (Table 1 and Additional file 1: Table S1). Gas bubbles from the natural gas seeps for 
which the concentrations of methane, ethane and propane have not been reported were also sampled for subsequent assays using gas chromatography (Table 1). Seeps from Romania mainly releasing thermogenic methane $[5,6]$ or potentially biogenic methane [50] were also sampled (Table 1 and Additional file 1: Table S1). The investigated features appear as mud volcanoes (Paclele Mari, Paclele Mici, Beciu) or dry seeps generating everlasting fires (Andreiasu). Samples were also taken from wetland environments known for biogenic methane emissions as a result of microbial methanogenic activity, e.g. Lakenheath Fen Nature Reserve (Norfolk, UK), Moor House Nature Reserve (Pennine Hills, UK), Church Farm soil (Bawburgh, Norfolk, UK) and Stiffkey and Warham salt marshes (Norfolk, UK). Samples from Movile Cave (Romania), an unusual habitat known to have both methanogenic and thermogenic natural gas emissions, were also obtained [53]. Two to five sub-samples were taken from each sub-site in sterile $50 \mathrm{ml}$ plastic tubes, which were pooled together before DNA extraction in the lab. The $\mathrm{pH}$ of samples was measured in the lab using a $\mathrm{pH}$ meter (Jenway) using 1:5 ( $w /$ w) soil water suspensions in the case of soil or sediment samples or directly in the case of water samples.

\section{Measurement of gaseous hydrocarbons by gas chromatography}

Alkane $(\mathrm{C} 1-\mathrm{C} 3)$ concentrations in the gas samples at seep sites were quantified using a gas chromatograph (GC). From bubbles, $5 \mathrm{ml}$ gas was taken into a syringe and injected into $30 \mathrm{ml}$ pre-sealed serum vial. These vials were analysed in the lab using an Agilent 7820A GC equipped with a Porapak Q column (Supelco) coupled to a flame ionisation detector (FID) to measure methane, ethane and propane concentrations as previously described [46].

\section{Extraction of DNA and PCR amplification of 16S rRNA and mmoX genes}

DNA was extracted from pure cultures of methanotrophic strains using standard methods [73]. DNA was extracted from soils, sediments or slurries using the FAST DNA spin kit for soil (MP Biomedicals), following the manufacturer's instructions. Qubit (Invitrogen), NanoDrop (ThermoFisher Scientific) and gel electrophoresis methods were used to check quantity and quality of DNA samples.

All primers used in this study are listed in Table S5 (Additional file 1). Extracted DNA was used as the template for PCR to amplify $16 \mathrm{~S}$ rRNA and $m m o X$ genes. Initially, the absence of PCR inhibitors, such as humic acids, was confirmed by amplifying bacterial $16 \mathrm{~S}$ rRNA genes from template DNA, extracted from all the samples, using universal primers $27 \mathrm{~F}$ and $1492 \mathrm{R}$ [75].
Reactions were carried out in a $20-\mu \mathrm{l}$ volume consisting of $10 \mu \mathrm{l}$ PCRBIO Taq mix red (2x) (PCRBIO), $0.8 \mu \mathrm{l}$ of each of forward and reverse primers $(10 \mu \mathrm{M})$ and $0.8 \mu \mathrm{l}$ of template DNAs ( 1 to $10 \mathrm{ng}$ ). The cycling conditions for PCR amplification of $16 \mathrm{~S}$ rRNA genes were $95^{\circ} \mathrm{C}$ for $3 \mathrm{~min}$, followed by 30 cycles of $94{ }^{\circ} \mathrm{C}$ for $20 \mathrm{~s}, 55^{\circ} \mathrm{C}$ for $20 \mathrm{~s}$ and $72{ }^{\circ} \mathrm{C}$ for $40 \mathrm{~s}$, with a final extension at $72{ }^{\circ} \mathrm{C}$ for $5 \mathrm{~min}$.

A new semi-nested PCR protocol was optimised targeting Methylocella-specific mmoX using a newly designed forward primer (mmoXLF2) and a previously designed reverse primer (mmoXLR) (Additional file 1: Table S5). For the amplification of $m m o X$ genes specifically from Methylocella by conventional PCR, a first round of PCR was adopted using primers mmoXLF and mmoXLR, while a second round of PCR was performed with primers mmoXLF2 and mmoXLR. PCR reactions were carried out in a $20-\mu \mathrm{l}$ volume containing $10 \mu \mathrm{l}$ PCRBIO Taq mix red (2×) (PCRBIO), $0.8 \mu \mathrm{l}$ of each of forward and reverse primers $(10 \mu \mathrm{M})$ and $0.8 \mu \mathrm{l}$ of template DNA (5 to $20 \mathrm{ng}$ ) or $0.8 \mu \mathrm{l}$ first round PCR product. PCR cycling conditions for both PCR assays consisted of a touchdown programme, i.e. $95{ }^{\circ} \mathrm{C}$ for $3 \mathrm{~min}$, followed by 10 cycles of $94{ }^{\circ} \mathrm{C}$ for $20 \mathrm{~s}, 70$ to $61{ }^{\circ} \mathrm{C}$ (decreasing 1 each cycle) for $20 \mathrm{~s}, 72{ }^{\circ} \mathrm{C}$ for $20 \mathrm{~s}$ and then 25 cycles of $94{ }^{\circ} \mathrm{C}$ for $20 \mathrm{~s}, 60^{\circ} \mathrm{C}$ for $20 \mathrm{~s}$ and $72{ }^{\circ} \mathrm{C}$ for $20 \mathrm{~s}$, with a final extension at $72{ }^{\circ} \mathrm{C}$ for $5 \mathrm{~min}$. For assays targeting specifically $m m o X$ from Methylocella, PCR conditions were optimised with DNA from pure cultures of Methylocella silvestris, Methylocella palustris, Methylocella tundrae and from Methylosinus trichosporium OB3b and Methylococcus capsulatus Bath as negative controls (Additional file 1: Figure S3). Specificity of the primers to detect $m m o X$ of Methylocella in environmental DNA was verified by clone library analysis using the pGEMT easy (Promega) cloning kit according to the manufacturer's instructions (Table 1) before carrying out Illumina amplicon sequence analyses (described below). Ninety-three clones (from 17 representative samples) were sequenced and analysed. All sequences obtained were $m m o X$ sequences (Table 1 ), of which only $5 \%$ were $m m o X$ sequences related to methanotrophs other than Methylocella, while all other sequences obtained appeared to be $m m o X$ sequences related to Methylocella, with $80-100 \%$ nucleotide identity to $m m o X$ from Methylocella. Moreover, no false-positive $m m o X$ sequences were detected in clone libraries from environments such as Moor House Nature Reserve and Andreiasu Everlasting Fire, where other $m m o X$-containing methanotrophs (Methylocystis, Methylococcus) were abundant (Fig. 2).

\section{Quantitative real-time PCR}

Quantification of Methylocella and other methanotrophs was estimated by qPCR assays targeting Methylocella-specific mmoX (using mmoXLF2 and mmoXLR primer pair yielding an amplicon size of $389 \mathrm{bp}$ ) and $p m o A$ (using A189F and Mb661R primer pair yielding an 
amplicon size of $472 \mathrm{bp}$ ) (see primer sequences in Additional file 1: Table S5). Quantification of 16S rRNA genes was also performed by qPCR using 519F and 907R primers (yielding an amplicon size of $388 \mathrm{bp}$ ). All qPCR assays were performed using StepOne Plus real-time PCR system (Applied Biosystems). Reactions were carried out in a 96-well qPCR plate (Applied Biosystems), in a total reaction volume of $20 \mu \mathrm{l}$, containing $10 \mu \mathrm{l}$ of $2 \times$ SensiFAST SYBR Hi-ROX reagent (Bioline), $0.8 \mu \mathrm{l}$ of each of forward and reverse primers $(10 \mu \mathrm{M})$ and $0.8 \mu \mathrm{l}$ of template DNAs or standards. Conditions for Methylocella-specific mmoX qPCR reactions consisted of an initial denaturation step at $95{ }^{\circ} \mathrm{C}$ for $3 \mathrm{~min}$, followed by 40 cycles of $95{ }^{\circ} \mathrm{C}$ for $20 \mathrm{~s}, 65^{\circ} \mathrm{C}$ for $30 \mathrm{~s}$ and $72{ }^{\circ} \mathrm{C}$ for $30 \mathrm{~s}$. Specificity of amplification was determined from dissociation curves obtained by increasing $1{ }^{\circ} \mathrm{C}$ per $30 \mathrm{~s}$ from 65 to $90{ }^{\circ} \mathrm{C}$ and after gel electrophoresis and clone library construction from qPCR products (data not shown). Conditions for $16 \mathrm{~S}$ rRNA gene and $p m o A$ qPCR reactions consisted of an initial denaturation step at $95{ }^{\circ} \mathrm{C}$ for $3 \mathrm{~min}$, followed by 40 cycles of $95{ }^{\circ} \mathrm{C}$ for $20 \mathrm{~s}, 55^{\circ} \mathrm{C}$ for $30 \mathrm{~s}$ and $72{ }^{\circ} \mathrm{C}$ for $30 \mathrm{~s}$. The gene copy numbers of Methylocella-specific mmoX and methanotrophic $p m o A$ genes per microgram of template DNA were determined using calibration curves obtained from qPCR of tenfold dilution series of DNA standards (Additional file 1: Figure S5). The detection limit of the qPCR assay was ten copies of mmoX of Methylocella per $20 \mu \mathrm{l} \mathrm{PCR}$ reaction (Additional file 1: Figure S5). The qPCR assay was validated by spiking Warham salt marsh soil (Norfolk, UK) with known numbers of Methylocella silvestris BL2 and Methylocella palustris $\mathrm{K}$ cells (ranging from $10^{3}$ to $10^{6}$ cells g $^{-1}$ soil) and by detecting the mmoX copies from the spiked soil (Additional file 1: Figure S6). Assuming two copies of $16 \mathrm{~S}$ rRNA gene per cell, a single copy of $m m o X$ gene per Methylocella cell [45] and two copies of $p m o A$ per cell [30] for other methanotrophs, the abundance of methanotrophs in different samples was estimated. Controls to check for any inhibition of the qPCR assay were also performed by carrying out a qPCR assay targeting the mmoX of Methylocella, using tenfold serial dilutions of environmental DNA samples and also by doing another Methylocella-specific mmoX qPCR assay where templates were environmental DNA samples spiked with known amounts of Methylocella silvestris BL2 genomic DNA. Both inhibition control experiments did not show any inhibition of amplification during PCR reactions (data not shown).

\section{Illumina Mi-Seq sequencing of PCR amplicons}

Illumina Mi-Seq sequencing of PCR amplicons obtained from environmental DNA samples and control samples with genomic DNA of Methylocella silvestris BL2 was performed for both 16S rRNA genes and Methylocella-specific mmoX genes. For $16 \mathrm{~S}$ rRNA genes, universal primers $341 \mathrm{~F}$ and $785 \mathrm{R}$ primers [76] targeting the $\mathrm{V} 3$ and $\mathrm{V} 4$ regions were used. PCR reactions were carried out in $25 \mu \mathrm{l}$ containing $12.5 \mu \mathrm{l} 2 \times$ PCRBIO Ultra Polymerase (PCR BIO), $1 \mu \mathrm{l}$ of each of forward and reverse primers $(10 \mu \mathrm{M})$ and $1 \mu \mathrm{l}$ of template DNA. The cycling conditions were $95{ }^{\circ} \mathrm{C}$ for $3 \mathrm{~min}$, followed by 25 cycles of $94{ }^{\circ} \mathrm{C}$ for $20 \mathrm{~s}, 55^{\circ} \mathrm{C}$ for $20 \mathrm{~s}$ and $72{ }^{\circ} \mathrm{C}$ for $30 \mathrm{~s}$, with a final extension at $72{ }^{\circ} \mathrm{C}$ for $5 \mathrm{~min}$. Duplicate PCR reactions for each sample were pooled before purifying using a NucleoSpin Gel and PCR Clean-up Kit (Macherey-Nagel). Gel electrophoresis and a NanoDrop machine were used to assess the quantity and quality of the purified PCR products, and concentrations of all samples were adjusted to 15-20 ng per microliter. Similarly, samples were prepared for Methylocella-specific mmoX amplicon sequencing using the primers and PCR assay described above for the detection of Methylocella in the environment. Purified PCR products were used to prepare DNA libraries following the Illumina TruSeq DNA library protocol and sequenced $(2 \times 300$ bp paired-end reads $)$ at MR DNA (Shallowater, TX, USA) using the Illumina MiSeq platform.

16S rRNA sequence data were processed using MR DNA proprietary analysis pipeline (www.mrdnalab.com). Sequences were depleted of barcodes and primers then short sequences $<200$ bp were removed, sequences with ambiguous base calls removed, and sequences with homopolymer runs exceeding $6 \mathrm{bp}$ removed. Sequences were then denoised, and 16S rRNA gene OTUs were defined with clustering at $3 \%$ divergence ( $97 \%$ similarity) followed by removal of singleton sequences and chimeras [77-82]. Final OTUs were taxonomically classified using BLASTn against a curated database derived from GreenGenes [83], RDPII (http://rdp.cme.msu.edu) and NCBI (www.ncbi.nlm.nih.gov), and compiled into each taxonomic level. Abundance data of $16 \mathrm{~S}$ rRNA gene OTUs related to Methylocella retrieved from the environments with known concentrations of ethane and propane (Additional file 1: Table S1) were used to calculate Spearman's correlation coefficient at the statistical significance level of 0.05 .

For Methylocella-specific $m m o X$ sequence data, paired-end reads were merged using VSEARCH v2.6.1 [84] using default parameters. Successfully merged reads were demultiplexed, and barcodes and primers are removed using Cutadapt v1.15 [85]. Sequences were filtered for ambiguous bases and de-replicated using VSEARCH, prior to de novo clustering using SwarmV2 v2.2.2 [72, 86], with the fastidious option. Finally, chimeras were removed and sequences quality filtered using VSEARCH. Representative sequences from each OTU were extracted for subsequent phylogenetic analysis. Phylogenetic trees were constructed using Mega7.0 [87]. 


\section{Additional files}

Additional file 1: Supplementary information. (PDF $1546 \mathrm{~kb}$ )

Additional file 2: Table S2. Bacterial abundance assessed by 165 rRNA. (XLSX $147 \mathrm{~kb}$ )

Additional file 3: Table S4. Methylocella-specific mmoX abundance. (XLSX $1606 \mathrm{~kb}$ )

\section{Acknowledgements}

We thank Alexandra Hillebrand-Voiculescu from Institute of Speleology (Romania) for providing Movile Cave samples, Niall McNamara and Simon Oakley from Lancaster Environment Centre (UK) for providing Moor House samples and the Lakenheath Fen Nature Reserve site team for facilitating the sample collection. We also thank William, Jerry, Doug and Bob for permission to collect samples from their land in New York State.

\section{Funding}

The work on this project was supported by the Leverhulme Trust Research Project (grant number RPG2016-050) to JCM and Leverhulme Trust Early Career Fellowship (grant number ECF2016-626) to ATC.

\section{Availability of data and materials}

Amplicon sequence data generated in this study were deposited to sequence read archives (SRA) under project number PRJNA434222, and clone library sequence data were deposited to NCBI GenBank under accession numbers MG992939 to MG993027. The data can be accessed using the following web link: https://www.ncbi.nlm.nih.gov/sra/ ?term $=$ Biology + and + Ecology + of + Facultative+Methanotrophs+Raw +sequence+reads

\section{Authors' contributions}

MFUH, ATC and JCM planned the experiments. ATC and SAE collected New York samples. CB collected Romania seep samples. MFUH and ATC carried out the experimental work and analysed the data. MFUH, ATC and JCM wrote the manuscript with contributions from all authors. All authors read and approved the final manuscript

\section{Ethics approval and consent to participate} Not applicable.

\section{Consent for publication}

Not applicable.

\section{Competing interests}

The authors declare that they have no competing interests.

\section{Publisher's Note}

Springer Nature remains neutral with regard to jurisdictional claims in published maps and institutional affiliations.

\section{Author details}

${ }^{1}$ School of Environmental Sciences, University of East Anglia, Norwich Research Park, Norwich NR4 7TJ, UK. ${ }^{2}$ School of Biological Sciences, University of East Anglia, Norwich Research Park, Norwich NR4 7TJ, UK. ${ }^{3}$ Western New York Waterfall Survey, North Tonawanda, New York, USA. ${ }^{4}$ Faculty of Environmental Science and Engineering, Babeş-Bolyai University, Cluj-Napoca, Romania.

Received: 28 February 2018 Accepted: 13 June 2018

\section{Published online: 28 June 2018}

\section{References}

1. Myhre GSD, Bréon FM, Collins W, Fuglestvedt J, Huang J, KochD LJF, Lee D, Mendoza B, Nakajima T, Robock A, Stephens G, Takemura T, Zhang H. Climate change 2013-the physical science basis; working group 1 contribution to the fifth assessment report. Intergovernmental Panel on Climate Change. Cambridge: Cambridge University Press; 2014.

2. EPA. Methane and nitrous oxide emissions from natural sources. vol. EPA 430-R-10-001. US Environmental Protection Agency; 2010.
3. Etiope G, Feyzullayev A, Baciu CL. Terrestrial methane seeps and mud volcanoes: a global perspective of gas origin. Mar Pet Geol. 2009;26:333-44

4. Etiope G, Ciccioli P. Earth's degassing: a missing ethane and propane source. Science. 2009;323:478.

5. Baciu C, Caracausi A, Etiope G, Italiano F. Mud volcanoes and methane seeps in Romania: main features and gas flux. Ann Geophyiology. 2007; 50:501-11.

6. Baciu C, lonescu A, Etiope G. Hydrocarbon seeps in Romania: gas origin and release to the atmosphere. Mar Pet Geol. 2018;89:130-43.

7. Kroeger KF, di Primio R, Horsfield B. Atmospheric methane from organic carbon mobilization in sedimentary basins-the sleeping giant? Earth Sci Rev. 2011:107:423-42.

8. Etiope G, Klusman RW. Microseepage in drylands: flux and implications in the global atmospheric source/sink budget of methane. Glob Planet Chang. 2010;72:265-74

9. Anthony KMW, Anthony P, Grosse G, Chanton J. Geologic methane seeps along boundaries of Arctic permafrost thaw and melting glaciers. Nat Geosci. 2012:5:419-26.

10. Tassi F, Fiebig J, Vaselli O, Nocentini M. Origins of methane discharging from volcanic-hydrothermal, geothermal and cold emissions in Italy. Chem Geol. 2012;310-311:36-48.

11. Oremland RS, Miller LG, Whiticar MJ. Sources and flux of natural gases from Mono Lake, California. Geochim Cosmochim Acta. 1987;51:2915-29.

12. Etiope G, Drobniak A, Schimmelmann A. Natural seepage of shale gas and the origin of "eternal flames" in the Northern Appalachian Basin, USA. Mar Pet Geol. 2013;43:178-86.

13. Reddy CM, Arey JS, Seewald JS, Sylva SP, Lemkau KL, Nelson RK, Carmichael CA, Mclntyre CP, Fenwick J, Ventura GT, et al. Composition and fate of gas and oil released to the water column during the Deepwater Horizon oil spill. Proc Natl Acad Sci U S A. 2012;109:20229-34.

14. Osborn SG, Vengosh A, Warner NR, Jackson RB. Methane contamination of drinking water accompanying gas-well drilling and hydraulic fracturing. Proc Natl Acad Sci U S A. 2011;108:8172-6.

15. Howarth RW, Santoro R, Ingraffea A. Methane and the greenhouse-gas footprint of natural gas from shale formations. Clim Chang. 2011;106: 679-90

16. Jackson RB, Vengosh A, Darrah TH, Warner NR, Down A, Poreda RJ, Osborn SG, Zhao K, Karr JD. Increased stray gas abundance in a subset of drinking water wells near Marcellus shale gas extraction. Proc Natl Acad Sci U S A. 2013;110:11250-5.

17. Wang $Q$, Chen $X$, Jha AN, Rogers $H$. Natural gas from shale formation-the evolution, evidences and challenges of shale gas revolution in United States. Renew Sust Energ Rev. 2014;30:1-28.

18. Kolb S. The quest for atmospheric methane oxidizers in forest soils. Environ Microbiol Rep. 2009;1:336-46.

19. Dunfield PF. The soil methane sink. In: Greenhouse gas sinks. Wallingford: CABI; 2007

20. Dalal RC, Allen DE. Greenhouse gas fluxes from natural ecosystems. Aust J Bot. 2008;56:369-407.

21. Semrau JD, DiSpirito AA, Vuilleumier S. Facultative methanotrophy: false leads, true results, and suggestions for future research. FEMS Microbiol Lett. 2011;323:1-12.

22. Vorobev A, Jagadevan S, Jain S, Anantharaman K, Dick GJ, Vuilleumier S, Semrau JD. Genomic and transcriptomic analyses of the facultative methanotroph Methylocystis sp. strain SB2 grown on methane or ethanol. Appl Environ Microbiol. 2014;80:3044-52.

23. Ross MO, Rosenzweig AC. A tale of two methane monooxygenases. J Biol Inorg Chem. 2017;22:307-19.

24. Trotsenko YA, Murrell JC. Metabolic aspects of aerobic obligate methanotrophy. In: Advances in Applied Microbiology. Washington, DC: vol. 63: Academic Press; 2008. p. 183-229.

25. Chistoserdova L. Modularity of methylotrophy, revisited. Environ Microbiol. 2011;13:2603-22

26. Chistoserdova L, Lidstrom ME. Aerobic methylotrophic prokaryotes. In: Rosenberg E, DeLong EF, Lory S, Stackebrandt E, Thompson F, editors. The prokaryotes: prokaryotic physiology and biochemistry. Berlin: Springer Berlin Heidelberg; 2013. p. 267-85.

27. Knief C. Diversity and habitat preferences of cultivated and uncultivated aerobic methanotrophic bacteria evaluated based on pmoA as molecular marker. Front Microbiol. 2015;6:1346. 
28. Ghashghavi M, Jetten MSM, Luke C. Survey of methanotrophic diversity in various ecosystems by degenerate methane monooxygenase gene primers. AMB Express. 2017;7:162.

29. Semrau JD, DiSpirito AA, Murrell JC. Life in the extreme: thermoacidophilic methanotrophy. Trends Microbiol. 2008;16:190-3.

30. Stein LY, Yoon S, Semrau JD, Dispirito AA, Crombie A, Murrell JC, Vuilleumier S, Kalyuzhnaya MG, Op den Camp HJ, Bringel F, et al. Genome sequence of the obligate methanotroph Methylosinus trichosporium strain OB3b. J Bacteriol. 2010;192:6497-8.

31. Ashraf W, Mihdhir A, Murrell JC. Bacterial oxidation of propane. FEMS Microbiol Lett. 1994;122:1-6.

32. Tetsuya K, Yui K, Hiroya Y, Nobuo K, Yasuyoshi S. Gene structure and regulation of alkane monooxygenases in propane-utilizing Mycobacterium sp. TY-6 and Pseudonocardia sp. TY-7. J Biosci Bioeng. 2016;102(3):184-192.

33. Nicholas VC, Sheree Y, Neil LW, Laura MN, Margaret DM, Mai-anh L, Ben C, Andrew JH. Untangling the multiple monooxygenases of Mycobacterium chubuense strain NBB4, a versatile hydrocarbon degrader. Environ Microbiol Rep. 2011;3(3):297-307

34. Johnson EL, Hyman MR. Propane and n-butane oxidation by Pseudomonas putida GPo1. Appl Environ Microbiol. 2006;72:950-2.

35. Dubbels BL, Sayavedra-Soto LA, Arp DJ. Butane monooxygenase of Pseudomonas butanovora: purification and biochemical characterization of a terminal-alkane hydroxylating diiron monooxygenase. Microbiology. 2007;153:1808-16.

36. Dubbels BL, Sayavedra-Soto LA, Bottomley PJ, Arp DJ. Thauera butanivorans sp. nov., a C2-C9 alkane-oxidizing bacterium previously referred to as Pseudomonas butanovora. Int J Syst Evol Microbiol. 2009:59:1576-8.

37. Shennan JL. Utilisation of C2-C4 gaseous hydrocarbons and isoprene by microorganisms. J Chem Technol Biotechnol. 2006:81:237-56.

38. Cappelletti M, Presentato A, Milazzo G, Turner RJ, Fedi S, Frascari D, Zannoni D. Growth of Rhodococcus sp. strain BCP1 on gaseous n-alkanes: new metabolic insights and transcriptional analysis of two soluble di-iron monooxygenase genes. Front Microbiol. 2015;6:393.

39. Dedysh SN, Liesack W, Khmelenina VN, Suzina NE, Trotsenko YA, Semrau JD, Bares AM, Panikov NS, Tiedje JM. Methylocella palustris gen. nov., sp. nov., a new methane-oxidizing acidophilic bacterium from peat bogs, representing a novel subtype of serine-pathway methanotrophs. Int J Syst Evol Microbiol. 2000;50(Pt 3):955-69.

40. Dunfield PF, Khmelenina VN, Suzina NE, Trotsenko YA, Dedysh SN. Methylocella silvestris sp. nov., a novel methanotroph isolated from an acidic forest cambisol. Int J Syst Evol Microbiol. 2003;53:1231-9.

41. Dedysh SN, Berestovskaya YY, Vasylieva LV, Belova SE, Khmelenina VN, Suzina NE, Trotsenko YA, Liesack W, Zavarzin GA. Methylocella tundrae sp. nov., a novel methanotrophic bacterium from acidic tundra peatlands. Int J Syst Evol Microbiol. 2004;54:151-6.

42. Dedysh SN, Knief C, Dunfield PF. Methylocella species are facultatively methanotrophic. J Bacteriol. 2005;187:4665-70.

43. Theisen AR, Ali MH, Radajewski S, Dumont MG, Dunfield PF, McDonald IR, Dedysh $\mathrm{SN}$, Miguez CB, Murrell JC. Regulation of methane oxidation in the facultative methanotroph Methylocella silvestris BL2. Mol Microbiol. 2005;58:682-92.

44. Tamas I, Smirnova AV, He Z, Dunfield PF. The (d)evolution of methanotrophy in the Beijerinckiaceae - a comparative genomics analysis. ISME J. 2014;8:369-82.

45. Chen Y, Crombie A, Rahman MT, Dedysh SN, Liesack W, Stott MB, Alam M, Theisen AR, Murrell JC, Dunfield PF. Complete genome sequence of the aerobic facultative methanotroph Methylocella silvestris BL2. J Bacteriol. 2010; 192:3840-1.

46. Crombie AT, Murrell JC. Trace-gas metabolic versatility of the facultative methanotroph Methylocella silvestris. Nature. 2014;510:148-51.

47. Hall J. Geology of New York: survey of the fourth geological district. Albany: Carol and Cook; 1843.

48. Lyell C. Lyell's travels in North America in the years 1841-1842. NY: C. E. Merrill; 1909.

49. Macauley J. The natural, statistical and civil history of New York. Albany: Gould and Banks; 1829.

50. Alain K, Holler T, Musat F, Elvert M, Treude T, Kruger M. Microbiological investigation of methane- and hydrocarbon-discharging mud volcanoes in the Carpathian Mountains, Romania. Environ Microbiol. 2006;8:574-90.

51. Chen Y, Wu L, Boden R, Hillebrand A, Kumaresan D, Moussard H, Baciu M, Lu Y, Colin Murrell J. Life without light: microbial diversity and evidence of sulfur- and ammonium-based chemolithotrophy in Movile Cave. ISME J. 2009:3:1093.
52. Kumaresan D, Wischer D, Stephenson J, Hillebrand-Voiculescu A, Murrell JC. Microbiology of Movile Cave-a chemolithoautotrophic ecosystem. Geomicrobiol J. 2014;31:186-93.

53. Sarbu SM, Kane TC, Kinkle BK. A chemoautotrophically based cave ecosystem. Science. 1996;272:1953-5.

54. McDonald IR, Bodrossy L, Chen Y, Murrell JC. Molecular ecology techniques for the study of aerobic methanotrophs. Appl Environ Microbiol. 2008;74:1305-15.

55. Wang J, Geng K, Farhan UI Haque M, Crombie A, Street L, Wookey P, Ma K, Murrell JC, Pratscher J. Draft genome sequence of Methylocella silvestris TVC, a facultative methanotroph isolated from permafrost. Genome Announc. 2018:6:e00040-18.

56. Rahman MT, Crombie A, Chen Y, Stralis-Pavese N, Bodrossy L, Meir P, McNamara NP, Murrell JC. Environmental distribution and abundance of the facultative methanotroph Methylocella. ISME J. 2011;5:1061-6.

57. Kumaresan D, Stephenson J, Doxey AC, Bandukwala H, Brooks E, HillebrandVoiculescu A, Whiteley AS, Murrell JC. Aerobic proteobacterial methylotrophs in Movile Cave: genomic and metagenomic analyses. Microbiome. 2018;6:1

58. Kolb S, Knief C, Dunfield PF, Conrad R. Abundance and activity of uncultured methanotrophic bacteria involved in the consumption of atmospheric methane in two forest soils. Environ Microbiol. 2005;7:1150-61.

59. Kallistova A, Montonen L, Jurgens G, Munster U, Kevbrina MV, Nozhevnikova AN. Culturable psychrotolerant methanotrophic bacteria in landfill cover soil. Mikrobiologia. 2014;83:109-18.

60. Miller DN, Yavitt JB, Madsen EL, Ghiorse WC. Methanotrophic activity, abundance, and diversity in forested swamp pools: spatiotemporal dynamics and influences on methane fluxes. Geomicrobiol J. 2004;21:257-71.

61. Dedysh SN, Panikov NS, Liesack W, Großkopf R, Zhou J, Tiedje JM. Isolation of acidophilic methane-oxidizing bacteria from northern peat wetlands. Science. 1998;282:281-4.

62. Radajewski S, Webster G, Reay DS, Morris SA, Ineson P, Nedwell DB, Prosser $\mathrm{Jl}$, Murrell JC. Identification of active methylotroph populations in an acidic forest soil by stable-isotope probing. Microbiology. 2002;148:2331-42.

63. Chen Y, Dumont MG, McNamara NP, Chamberlain PM, Bodrossy L, StralisPavese N, Murrell JC. Diversity of the active methanotrophic community in acidic peatlands as assessed by mRNA and SIP-PLFA analyses. Environ Microbiol. 2008:10:446-59.

64. Putkinen A, Larmola T, Tuomivirta T, Siljanen HMP, Bodrossy L, Tuittila E-S, Fritze $\mathrm{H}$. Peatland succession induces a shift in the community composition of Sphagnum-associated active methanotrophs. FEMS Microbiol Ecol. 2014; 88:596-611.

65. Meyer KM, Klein AM, Rodrigues JLM, Nüsslein K, Tringe SG, Mirza BS, Tiedje JM, Bohannan BJM. Conversion of Amazon rainforest to agriculture alters community traits of methane-cycling organisms. Mol Ecol. 2017;26:1547-56.

66. Morris SA, Radajewski S, Willison TW, Murrell JC. Identification of the functionally active methanotroph population in a peat soil microcosm by stable-isotope probing. Appl Environ Microbiol. 2002;68:1446-53.

67. Liebner S, Svenning MM. Environmental transcription of mmoX by methane-oxidizing proteobacteria in a subarctic palsa peatland. Appl Environ Microbiol. 2013:79:701-6.

68. Dedysh SN, Derakshani M, Liesack W. Detection and enumeration of methanotrophs in acidic sphagnum peat by $16 \mathrm{~S}$ rRNA fluorescence in situ hybridization, including the use of newly developed oligonucleotide probes for Methylocella palustris. Appl Environ Microbiol. 2001;67:4850-7.

69. Duddleston KN, Kinney MA, Kiene RP, Hines ME: Anaerobic microbial biogeochemistry in a northern bog: acetate as a dominant metabolic end product. Glob Biogeochem Cycles 2002;16:11-11-11-19.

70. Vekeman B, Kerckhof FM, Cremers G, de Vos P, Vandamme P, Boon N, Op den Camp HJ, Heylen K. New Methyloceanibacter diversity from North Sea sediments includes methanotroph containing solely the soluble methane monooxygenase. Environ Microbiol. 2016;18:4523-36.

71. Dedysh SN, Naumoff DG, Vorobev AV, Kyrpides N, Woyke T, Shapiro N, Crombie AT, Murrell JC, Kalyuzhnaya MG, Smirnova AV, Dunfield PF. Draft genome sequence of Methyloferula stellata AR4, an obligate methanotroph possessing only a soluble methane monooxygenase. Genome Announc. 2015;3:e01555-14

72. Mahé F, Rognes T, Quince $C$, de Vargas C, Dunthorn M. Swarm v2: highlyscalable and high-resolution amplicon clustering. PeerJ. 2015;3:e1420.

73. Crombie A, Murrell JC. Development of a system for genetic manipulation of the facultative methanotroph Methylocella silvestris BL2. In: Rosenzweig 
AC, Ragsdale SW, editors. Methods in Enzymology, vol. 495. Burlington: Academic Press; 2011. p. 119-33.

74. Whittenbury R, Phillips KC, Wilkinson JF. Enrichment, isolation and some properties of methane-utilizing bacteria. Microbiology. 1970;61:205-18.

75. Lane DJ. 16S/23S rRNA sequencing. New York: John Wiley \& Sons; 1991.

76. Klindworth A, Pruesse E, Schweer T, Peplies J, Quast C, Horn M, Glöckner FO. Evaluation of general $16 \mathrm{~S}$ ribosomal RNA gene PCR primers for classical and next-generation sequencing-based diversity studies. Nucleic Acids Res. 2013;41:e1.

77. Edgar RC. Search and clustering orders of magnitude faster than BLAST. Bioinformatics. 2010;26:2460-1.

78. Dowd SE, Sun Y, Wolcott RD, Domingo A, Carroll JA. Bacterial tag-encoded FLX amplicon pyrosequencing (bTEFAP) for microbiome studies: bacterial diversity in the ileum of newly weaned Salmonella-infected pigs. Foodborne Pathog Dis. 2008:5:459-72.

79. Dowd SE, Callaway TR, Wolcott RD, Sun Y, McKeehan T, Hagevoort RG, Edrington TS. Evaluation of the bacterial diversity in the feces of cattle using 165 rDNA bacterial tag-encoded FLX amplicon pyrosequencing (bTEFAP). BMC Microbiol. 2008:8:125.

80. Eren AM, Zozaya M, Taylor CM, Dowd SE, Martin DH, Ferris MJ. Exploring the diversity of Gardnerella vaginalis in the genitourinary tract microbiota of monogamous couples through subtle nucleotide variation. PLoS One. 2011; 6:e26732.

81. Capone KA, Dowd SE, Stamatas GN, Nikolovski J. Diversity of the human skin microbiome early in life. J Investig Dermatol. 2011;131:2026-32.

82. Swanson KS, Dowd SE, Suchodolski JS, Middelbos IS, Vester BM, Barry KA, Nelson KE, Torralba M, Henrissat B, Coutinho PM, et al. Phylogenetic and gene-centric metagenomics of the canine intestinal microbiome reveals similarities with humans and mice. ISME J. 2011;5:639-49.

83. T. Z. DeSantis, P. Hugenholtz, N. Larsen, M. Rojas, E. L. Brodie, K. Keller, T. Huber, D. Dalevi, P. Hu, G. L. Andersen. Greengenes, a chimera-checked $16 \mathrm{~S}$ rRNA gene database and workbench compatible with ARB. Appl Environ Microbio. 2006;72(7):5069-5072.

84. Rognes T, Flouri T, Nichols B, Quince C, Mahe F. VSEARCH: a versatile open source tool for metagenomics. PeerJ. 2016;4:e2584.

85. Martin M. Cutadapt removes adapter sequences from high-throughput sequencing reads. EMBnet J. 2011;17:10-2

86. Mahé F, Rognes T, Quince C, de Vargas C, Dunthorn M. Swarm: robust and fast clustering method for amplicon-based studies. PeerJ. 2014;2:e593.

87. Kumar S, Stecher G, Tamura K. MEGA7: molecular evolutionary genetics analysis version 7.0 for bigger datasets. Mol Biol Evol. 2016;33:1870-4.

\section{Ready to submit your research? Choose BMC and benefit from:}

- fast, convenient online submission

- thorough peer review by experienced researchers in your field

- rapid publication on acceptance

- support for research data, including large and complex data types

- gold Open Access which fosters wider collaboration and increased citations

- maximum visibility for your research: over $100 \mathrm{M}$ website views per year

At BMC, research is always in progress.

Learn more biomedcentral.com/submissions 